\title{
APPARENT RECOVERY OF FERTILIZER NITROGEN
}

\author{
ARMi KaILA \\ University of Helsinki, Department of Agricultural Chemistry
}

Received January 26, 1965

The relatively scanty information in the textbooks about the recovery of fertilizer nitrogen by crops is surprisingly conflicting. Some German textbooks declare that from 60 to 90 per cent (15), or from 70 to 90 per cent (11) of the nitrogen applied in artificial fertilizers is utilized by the plants. Russell (12), on the other hand, states that crops that respond to nitrogen manuring commonly take up and fix in their mature tissue between one-third and one-half of the nitrogen added as sulphate of ammonia, and a rather higher proportion of nitrogen as nitrate. ScHMaLFuss (14) emphasizes the large variation in the recovery of nitrogen from mineral fertilizers and suggests that 80 per cent would represent a general average value.

This contradictory information may partly be a consequence of differences in the climatic conditions and soil properties which determine the level of yield and the extent of the losses of nitrogen by leaching, denitrification, immobilization, or by other ways. It is likely that the rate of the application of fertilizers is of importance, and the cultivated plant in question and the system of cropping most certainly play their role.

Attention is also called to the fact that the material on the basis of which the recovery of fertilizer nitrogen could be estimated is relatively meager. In most field experiments the effectiveness of the fertilizers is determined only on the basis of the dry matter yields, and relatively seldom chemical analyses of the harvested plants are available. Unfortunately, results of the recovery of fertilizer nitrogen are in some papers reported on the basis of incorrect computations, and this, of course, only enhances the variation.

These problems are treated in the present paper. The material consists of data collected from published results concerning the recovery of fertilizer nutrients. In addition to these, also some field experiments reported in a previous paper (4) are studied from this point of view and supplemented by results of chemical analyses of the corresponding soils.

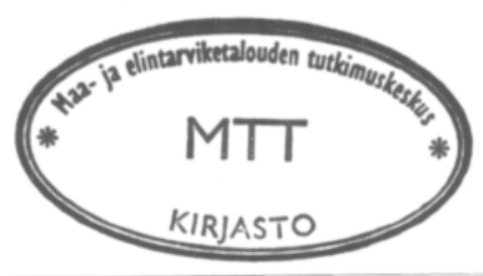




\section{Estimation of the recovery of nutrients by crops}

Under the field conditions, the determination of the uptake of nutrients applied in fertilizers does not seem to be quite simple. The relatively high expenses limit the use of fertilizers marked by radioactive or other isotopes in ordinary field experiments. Thus, the apparent recovery of a nutrient added in the fertilizer has to be computed on the basis of the difference in the contents of this nutrient in the crop fertilised and in the crop which did not receive the nutrient in question. It is of particular importance that the treatments differ only in regard to this nutrient. If there are differences also in the application of other nutrients, the results are less reliable.

This may be proved e. g. by examining some data reported in a paper by SALONEN and TAINIO (13) concerning the manuring and fertilizing of a clay soil. In this rotation experiment the total amounts of nitrogen in the crops of 21 years from the various treatments are reported to be the following:
0: $1063 \mathrm{~kg} \mathrm{~N}$
PK: $1196 \mathrm{~kg} \mathrm{~N}$
NKP: $1260 \mathrm{~kg} \mathrm{~N}$

It is apparent that the crops receiving phosphorus and potassium have been able to take up more soil nitrogen than the crops without any fertilizers. Thus the recovery of the fertilizer nitrogen in the NPK-treatment must be calculated as the difference between the nitrogen contents of the crops from NPK and PK. This is $64 \mathrm{~kg} \mathrm{~N}$, or 19.6 per cent of the total amount of nitrogen applied, $326 \mathrm{~kg}$. This apparent recovery is considerably lower than the percentage calculated by these writes on the basis of the difference NPK minus 0 which is as high as 60.4 per cent of the amount added.

In the same experiment the crops contained phosphorus:
0: $362 \mathrm{~kg} \mathrm{P}_{2} \mathrm{O}_{5}$
NK: $380 \mathrm{~kg} \mathrm{P}_{2} \mathrm{O}_{5}$
NPK: $449 \mathrm{~kg} \mathrm{P}_{2} \mathrm{O}_{5}$

It appears that the application of nitrogen and potassium has not markedly increased the uptake of soil phosphorus in this case. The apparent recovery of fertilizer phosphorus, the difference NPK minus NK is $69 \mathrm{~kg} \mathrm{P}_{2} \mathrm{O}_{5}$ or 8.2 per cent of the $840 \mathrm{~kg}$ $\mathrm{P}_{2} \mathrm{O}_{5}$ applied, not the 10.4 per cent reported on the basis of the difference NPK minus 0 .

The potassium contents of the crops were:
0: $1484 \mathrm{~kg} \mathrm{~K}_{2} \mathrm{O}$
NP: $1843 \mathrm{~kg} \mathrm{~K} \mathrm{~K}_{2} \mathrm{O}$
NPK: $1978 \mathrm{~kg} \mathrm{~K} \mathrm{~K}_{2} \mathrm{O}$

Thus, in this soil the improvement of the nitrogen and phosphorus supply has increased the utilization of the soil potassium to such an extent that the apparent recovery of the fertilizer potassium, NPK minus $\mathrm{NP}$, is only $135 \mathrm{~kg} \mathrm{~K}_{2} \mathrm{O}$, or 16.1 per cent of the $840 \mathrm{~kg} \mathrm{~K} \mathrm{~K}_{2} \mathrm{O}$ applied. The difference between the potassium content of the crops from NPK and 0 would represent 58.8 per cent of the amount added.

The fact that the application of certain nutrients may even markedly inflúence the uptake of an other nutrient either from the soil of from the fertilizer applied, has been left unnoticed also in other papers, e.g. in some works by IVERSEN and Dorph-Petersen $(5,6,7)$. The mistake which is made when the apparent recovery of a certain nutrient is calculated on the basis of the differences in the content of this nutrient in the crop receiving a complete fertilizer treatment and in the unferti- 
lized crop, depends, of course, on the supply of these other nutrients in the particular soil. In any case, however, too high estimations for the apparent recovery of nutrients applied in fertilizers has in this way got into circulation in the literature.

\section{Apparent recovery of fertilizer nitrogen in field experiments}

Gra s s l a n d. Cooke (3) emphasizes the fact that grassland recovers much larger proportions of nitrogen fertilizer dressings than arable crops do. On the basis of English and American data, he suggests that on average two-thirds to threequarters of the applied nitrogen is taken by grass and from soils low in total nitrogen almost all may be recovered. This is likely to be due to the lower rate of nitrogen losses through denitrification and leaching in a grassland than in an arable soil.

JÄNTTI and KöYLIJÄRVI (8) have published results on experiments concerning nitrogen fertilization on pastures in Finland. In six years the recovery of nitrogen in calcium nitrate applied at the annual rates of 400,800 , or $1260 \mathrm{~kg} / \mathrm{ha}$ was reported to be the following:

\begin{tabular}{|c|c|c|c|c|}
\hline year & $\mathrm{N}$ applied & $62 \mathrm{~kg} / \mathrm{ha}$ & $124 \mathrm{~kg} / \mathrm{ha}$ & $195 \mathrm{~kg} / \mathrm{ha}$ \\
\hline 1951 & & $81 \%$ & $25 \%$ & $30 \%$ \\
\hline 1952 & & $72 \%$ & $53 \%$ & $32 \%$ \\
\hline 1953 & & $87 \%$ & $29 \%$ & $60 \%$ \\
\hline 1954 & & $45 \%$ & $35 \%$ & $45 \%$ \\
\hline 1955 & & $43 \%$ & $21 \%$ & $19 \%$ \\
\hline 1956 & & $62 \%$ & $86 \%$ & - \\
\hline Average & & $65 \%$ & $46 \%$ & $33 \%$ \\
\hline
\end{tabular}

The variation is large ranging from 43 to 87 per cent of the lowest application, from 21 to 86 per cent of the second one, and from 19 to 60 per cent from the highest one. It seems that the differences in the climatic conditions are not decisive, since the variation is not connected with the experimental years. The age of the ley appears to be of more importance, as may be noted on the basis of figures of the recovery of nitrogen in the younger and older leys:

$\begin{array}{lrrrr}\begin{array}{c}\text { Calcium nitrate } \\ \text { applied }\end{array} & \text { 1st year } & \text { 2nd year } & \text { 3rd year } & 4-5 \text { th year } \\ 400 \mathrm{~kg} / \mathrm{ha} & 35 \% & 75 \% & 73 \% & 77 \% \\ 800 \% & 39 \% & 50 \% & 67 \% & 67 \% \\ 1260 & 43 \% & 37 \% & 49 \% & 59 \%\end{array}$

The first-year ley has been able to take up from the lowest calcium nitrate dressing less than one half of that the second-year ley has utilized. A tendency to a higher recovery with the age of the ley is apparent, although not quite regular. The fact that the seed contained red clover and white clover in addition to timothy and cocksfoot may explain the lower recovery by the first-year ley of fertilizer nitrogen from the application of $400 \mathrm{~kg} / \mathrm{ha}$ than from the highest application which probably markedly limited the assimilation of atmospheric nitrogen by the legumes. 
$\mathrm{R}$ ot a t i o n experiments. According to the classical field experiments by WAGNER (16), the recovery of nitrogen from Chilean nitrate dressings is about 60 to 62 per cent, provided the application of the fertilizer is not too heavy. WAGNER states that some residual effect of the fertilizer, due to the fertilizer nitrogen in the plant residues, may be taken into account: the utilization of fertilizer nitrogen in the first rotation was 52 per cent, and in the second rotation 64 per cent.

IVERSEN (5) reports results from 17 rotation experiments in which Chilean nitrate or ammonium sulphate was applied to the root crops in rotation containing summer wheat, oats and winter wheat as the second, third, and fourth crop, respectively. The average uptake of fertilizer nitrogen by the crops of the total rotation was 70.6 per cent from Chilean nitrate and 65.7 per cent from ammonium sulphate. Somewhat lower recovery is reported for rotations containing potato instead of root crops, 41,3 per cent of the Chilean nitrate and 37.6 per cent of the ammonium sulphate dressings. This is, at least partly, due to the fact that the tops of the potato were not included. The recovery of nitrogen from Chilean nitrate in an other series, in the PK-experiments, is reported to be 73.5 per cent of an application of $75 \mathrm{~kg} \mathrm{~N} / \mathrm{ha}$, and 70.5 per cent of the application of $150 \mathrm{~kg} \mathrm{~N} / \mathrm{ha}$. These figures are, however, calculated on the basis of the differences in the nitrogen contents of the crops from the treatments of NPK and 0 . Therefore, it is likely that they are too high.

Iversen and Dorph-Petersen $(6,7)$ have published results of valuable longterm rotation experiments in Denmark during the years 1894-1948. In these experiments mineral nitrogen has been applied as Chilean nitrate or calcium nitrate to cereals, Chilean nitrate to root crops, and ammonium sulphate to potatoes. The recovery of fertilizer nitrogen is reported to range from 63 to 104 per cent. An examination of the data reveals, however, that the highest values originate from the differences NPK -0 . Fortunately, there are also results on the basis of which the actual apparent recovery of fertilizer nitrogen may be calculated. These data are collected in Table 1 . They represent average recovery of nitrogen by the different crops and by the whole rotation. It is obvious that the effect of legumes and the possible residual effect of fertilizer nitrogen are included in these figures. Since only tubers of potato are analysed for nitrogen, the values obtained for the recovery of fertilizer nitrogen by potato and by rotations containing potato are too low. Attention is called to the fact that the values for the whole rotation are not simple sums of the data for the different crops, since the ratio of the root crops to potato varied during the experimental period.

The highest apparent recovery of fertilizer nitrogen in the whole rotation is 55 per cent in the Lundgaard-experiment. The Askov-experiment on the sand soil has given a recovery of 47 per cent. The low recovery in the Tylstrup-experiment, 23 per cent, is likely to be partly due to the apperently marked assimilation of free nitrogen by the legumes receiving potassium and phosphorus. In the other experiments the recovery of nitrogen from the plots without potassium or phosphate dressings are lower than from plots receiving all these nutrients.

The root crops appear to recover the fertilizer nitrogen efficiently, provided a shortage of the other nutrients is not a limiting factor. The high apparent recovery 
Table 1. Apparent recovery of fertilizer nitrogen in rotation experiments of IVERSEN and DORPHPetersen $(6,7)$

\begin{tabular}{cccc}
\multicolumn{4}{c}{ Apparent recovery of $\mathrm{N}$ as the difference } \\
\cline { 2 - 3 } $\begin{array}{c}\mathrm{N} \\
\mathrm{kg} / \mathrm{ha}\end{array}$ & $\mathrm{N}-0$ & $\frac{\mathrm{NP}-\mathrm{P}}{\mathrm{kg} / \mathrm{ha} \%} \frac{\mathrm{NK}-\mathrm{K}}{\mathrm{kg} / \mathrm{ha} \%} \frac{\mathrm{NPK}-\mathrm{PK}}{\mathrm{kg} / \mathrm{ha} \%} \quad \frac{\mathrm{kg} / \mathrm{ha} \%}{}$
\end{tabular}

Lundgaard $1931-38$

1. Winter cereal

2. Root crop or potato

3. Summer cereal

4. Clover-grass ley Total Tylstrup 1931-42

1. Winter cereal

2. Root crop or potato

3. Summer cereal

4. Clover-grass ley Total Askov $1931-38,44-47$ Loam soil

1. Winter cereal

2. Root crop

3. Summer cereal

4. Clover-grass ley Total Sand soil

1. Winter cereal

2. Root crop or potato

3. Summer cereal

4. Clover-grass ley Total

70
160
160
50
0
280

70

160

160

50

0

280

$$
44-47
$$

68
160
50
0
278

$$
68
$$

160

160

50

0

278

$\begin{array}{rrrr}20 & 29 & 26 & 37 \\ 99 & 62 & 141 & 88 \\ 27 & 17 & 27 & 17 \\ 22 & 44 & 3 & 6 \\ (-4) & - & (-8) & - \\ 101 & 36 & 166 & 38\end{array}$

$\begin{array}{rc}17 & 24 \\ 71 & 44 \\ 47 & 29 \\ 13 & 26 \\ (-8) & - \\ 72 & 26\end{array}$

$\begin{array}{rr}28 & 40 \\ 166 & 104 \\ 45 & 28 \\ 20 & 40 \\ 1 & - \\ 155 & 55\end{array}$

$-$

$-$

$-$

- -

$-$

$-\quad-$

$\begin{array}{rc}32 & 46 \\ 95 & 59 \\ 73 & 46 \\ 16 & 32 \\ (-39) & - \\ 89 & 32\end{array}$

$32 \quad 46$

$\begin{array}{ll}79 & 49\end{array}$

$60 \quad 38$

1530

$16-$

$123 \quad 44$

$\begin{array}{rr}21 & 31 \\ 0 & 0 \\ 28 & 56 \\ (-20) & - \\ 30 & 11\end{array}$
$28 \quad 41$
$\begin{array}{ll}71 & 44\end{array}$
$28 \quad 56$
(- 8) -
$120 \quad 43$

$\begin{array}{rr}21 & 31 \\ 61 & 38 \\ 12 & 8 \\ 23 & 46 \\ (-9) & - \\ 72 & 26\end{array}$

$\begin{array}{ll}- & - \\ - & - \\ - & - \\ - & - \\ - & - \\ & \\ - & - \\ - & - \\ - & - \\ - & - \\ - & - \\ - & -\end{array}$

$\begin{array}{rr}- & - \\ - & - \\ - & - \\ - & - \\ - & - \\ & \\ 31 & 46 \\ 96 & 60 \\ 67 & 42 \\ 34 & 68 \\ (-14) & - \\ 132 & 47\end{array}$

in the Lundgaard-experiment, 104 per cent, obviously indicates the occurence of some residual effect of nitrogen. The summer cereals and the winter cereals have taken up from 30 to 68 per cent of the nitrogen applied. The variation in the apparent recovery by the different crops is large, from 0 to 104 per cent, but it remains in half of the cases between 30 and 50 per cent.

On the basis of the results of some of these experiments (6) it is possible also to calculate the apparent recovery of fertilizer nitrogen applied in addition to farmyard manure containing an equal amount of nitrogen. From the $140 \mathrm{~kg} \mathrm{~N} / \mathrm{ha}$ the average uptake during the whole rotations was 53 per cent in the Lundgaardexperiment and 49 per cent in the Tylstrup-ecperiment. 
In the Finnish rotation experiment reported by SALONEN and TAInio (13) the crops were rye, 4 or 5 leys, oats, root crops, peas and oats, and fallow. Nitrogen was applied as calcium nitrate, the total amount during the experimental period of 25 years was $326 \mathrm{~kg} \mathrm{~N} / \mathrm{ha}$. As calculated above, the apparent recovery of this fertilizer nitrogen was only about 20 per cent. In the treatments which included manuring with 80 tons of farmyard manure per hectare during one rotation the apparent recovery of fertilizer nitrogen was 53 per cent when the manure was divided between the fallow and the root crop, but only 10 per cent, when also leys got their part from this total amount. It is likely that the former value is not reliable, since in these treatments the nitrogen content of the crops is reported to be $1142 \mathrm{~kg}$ without any fertilizers which is higher than the $1127 \mathrm{~kg} \mathrm{~N}$ obtained with PK. In the latter treatments the corresponding figures are $1118 \mathrm{~kg} \mathrm{~N}$ and $1208 \mathrm{~kg} \mathrm{~N}$, respectively. The writers themselves call attention to the uncertainty arising from the fact that the nitrogen yields of some years had to be estimated on the basis of general average data.

Lipman et al. (10) found in field experiments using a five-year rotation of corn, oats, wheat and timothy that the over all nitrogen recoveries during the 20 years period were for the different nitrogen sources:

$\begin{array}{lcccc} & \begin{array}{c}\text { calcium } \\ \text { nitrate }\end{array} & \begin{array}{c}\text { ammonium } \\ \text { sulphate }\end{array} & \begin{array}{c}\text { Chilean } \\ \text { nitrate }\end{array} & \begin{array}{c}\text { calcium } \\ \text { cyanamide }\end{array} \\ \text { from the limed soils } & 42 \% & 42 \% & 33 \% & 36 \% \\ \text { from the unlimed soils } & 32 \% & 21 \% & 37 \% & 33 \%\end{array}$

The acidity of the soil appears to have exerted an effect particularly on the utilisation of ammonium sulphate and calcium nitrate.

On the basis of data reported by White and Holben (18) the apparent recovery of fertilizer nitrogen in a four-year grain rotation may be computed. The average recoveries from the various applications were, during the period from 1881 to 1921 , 41 per cent from $480 \mathrm{lb} \mathrm{N} /$ acre, 24 per cent from $960 \mathrm{lb} \mathrm{N} /$ acre and 18.5 per cent from $1440 \mathrm{lb} \mathrm{N} /$ acre.

BoAwn and Nelson (2) have studied the upptake of nitrogen from different fertilizers applied at various rates in a rotation containing sorghum, potatoes, sugar beets, and sorghum. On the basis of their results the apparent recoveries of fertilizer nitrogen were calculated and recorded in Table 2. The recovery of nitrogen from calcium nitrate is very low by the sorghum crops in 1953, and about twice as high in 1956, yet only about one half of that from ammonium sulphate in this experiment. The potatoes have efficiently taken up nitrogen from all sources, and in the figures for the sugar beets the residual effect of nitrogen fertilizers is apparent. It is reported that all crops, including two corns without nitrogen applied, took up 88.4 per cent from ammonium sulphate, 85.9 per cent from ammonium nitrate, and 82.7 per cent from calcium nitrate, when all these fertilizers were applied at the rate of $160 \mathrm{lb} \mathrm{N} / \mathrm{acre}$.

It would be likely that fertilizer nitrogen from a lower application would be recovered to a larger extent than from a heavier application. This is the case in the 
Table 2. Apparent recovery of fertilizer nitrogen in field experiment of BoAwN and NELSON (2)

\begin{tabular}{|c|c|c|c|c|c|}
\hline \multirow[b]{2}{*}{ Source of $\mathrm{N}$} & \multirow[b]{2}{*}{$\begin{array}{l}\text { applied } \\
\text { lb/acre }\end{array}$} & \multicolumn{4}{|c|}{$\mathrm{N}$ recovered as a percentage of $\mathrm{N}$ applied } \\
\hline & & $\begin{array}{c}1953 \\
\text { Sorghum }\end{array}$ & $\begin{array}{c}1954 \\
\text { Potatoes }\end{array}$ & $\begin{array}{c}1955 \\
\text { Sugar beets }\end{array}$ & $\begin{array}{c}1956 \\
\text { Sorghum }\end{array}$ \\
\hline \multirow{3}{*}{$\begin{array}{l}\text { Ammonium } \\
\text { sulphate }\end{array}$} & 40 & 28 & 79 & 87 & 57 \\
\hline & 80 & 47 & 76 & 105 & 80 \\
\hline & 160 & 44 & 77 & 113 & 103 \\
\hline \multirow{3}{*}{$\begin{array}{l}\text { Ammonium } \\
\text { nitrate }\end{array}$} & 40 & 21 & 100 & 94 & 43 \\
\hline & 80 & 32 & 85 & 118 & 47 \\
\hline & 160 & 33 & 75 & 131 & 59 \\
\hline \multirow{3}{*}{$\begin{array}{l}\text { Calcium } \\
\text { nitrate }\end{array}$} & 40 & 16 & 89 & 86 & 39 \\
\hline & 80 & 18 & 94 & 108 & 40 \\
\hline & 160 & 23 & 76 & 128 & 46 \\
\hline
\end{tabular}

experiment reported by White and Holben (18). In the experiment of BoAwn and Nelson (2) almost the contrary seems to be true, since only with a few exceptions the recovery tends to increase with the rate of dressing (Table 2). It is not easy to understand why this does happen already in the first year. The residual effect of the nitrogen fertilizers may, at least partly, explain these results for the third and fourth crops.

Kofoed and SøndergaARd (9) found that in two field experiments the root crops took up, on average, $81,77,74$, and 66 per cent of the nitrogen in Chilean nitrate applied at the rates of $400,800,1200$, and $1600 \mathrm{~kg} / \mathrm{ha}$, respectively. In the second year the uptake of fertilizer nitrogen by cereals was $64,68,67$, and 60 per cent, when $200,400,600$ and $800 \mathrm{~kg}$ of calcium nitrate was applied per hectare. In the third year the corresponding percentages were $44,45,49$, and 50 per cent, respectively. It is likely that residual effect of nitrogen fertilizers plays its role in the irregular recovery of fertilizer nitrogen by the cereals and in the decrease of the level of the recovery in the third year.

S u m m e r cerea ls. In 1959 and 1960 several field experiments with summer cereals were carried out in which calcium nitrate and ammonium nitrate limestone were compared as sources of nitrogen (4). These included five experiments in which both grain and straw were analysed for their content of nitrogen, and four in which only the grain yield was analysed. In order to find out whether there is any connection between the nitrogen conditions of the soil and the recovery of fertilizer nitrogen, the experimental soils were analysed also for their content of mobilizeable nitrogen and total nitrogen.

In Table 3 are listed properties of the experimental soils. Two of the experiments, V 1 and V 2, were on clay loam soils on the south coast of Finland, and four on silt soils in Central Finland, K 1, K 2, K 5, and $\mathrm{K} 6$. The experiment $\mathrm{T} 1$ was on a fen peat soil in East-Finland, and both the experiments L 1 and L 2 on 


\begin{tabular}{|c|c|c|c|c|c|c|}
\hline & Place & Kind of soil & $\mathrm{pH}$ & Org. C \% & Tot. N \% & $\begin{array}{c}\text { Mobilizeable } \\
\text { N ppm }\end{array}$ \\
\hline V 1 & Helsinki & clay loam & 4.5 & 5.8 & 0.49 & 440 \\
\hline $\mathrm{V}_{2}$ & , & , & 5.1 & 4.6 & 0.40 & 340 \\
\hline T 1 & Tohmajärvi & humus soil & 5.0 & 16.8 & 0.66 & 370 \\
\hline K 1 & Laukaa & silt & 5.4 & 2.5 & 0.18 & 150 \\
\hline K 2 & , & , & 5.3 & 2.2 & 0.16 & 180 \\
\hline K 5 & , & , & 5.5 & 2.5 & 0.16 & 150 \\
\hline K 6 & , & , & 5.5 & 2.5 & 0.18 & 150 \\
\hline L 1 & Hattula & heavy clay & 5.0 & 2.6 & 0.26 & 140 \\
\hline
\end{tabular}

the same heavy clay soil in the southern part of the country. The pH-values, measured in $0.01 \mathrm{M} \mathrm{CaCl}_{2}$, show that particularly the soil $\mathrm{V} 1$ is rather acid. Both clay loam soils are rich in organic carbon and total nitrogen. The other mineral soils have a far lower content of carbon and nitrogen. In the humus soil, these values are, of course, relatively high. In the last column results are reported on the determination of the ammonium nitrogen mobilized under anaerobic conditions during three weeks at $30^{\circ} \mathrm{C}$. This is a procedure introduced by WARING and BREMNER (17), who report that they have found a close correlation between the results of this estimation and the amounts of mineral nitrogen produced by incubation under aerobic conditions. In the present study the results obtained divide the experimental soils in two groups: in the samples from the experiments $\mathrm{V} 1, \mathrm{~V} 2$, and $\mathrm{T} 1$ the production of ammonium nitrogen has been about twice as high as that in the other soils.

The amounts of nitrogen removed by the grain and straw yields of oats in five of the experiments are reported in Table 4. The total nitrogen yields from the soils of $\mathrm{V} 1$ and $\mathrm{V} 2$ which received no nitrogen are relatively high, particularly in the less acid soil V 2. This is well in accordance with the content of mobilizeable nitrogen and total nitrogen in these soils. The nitrogen yield from the peat soil without nitrogen fertilizer dressing is low, probably indicating that the mineralization of its large supply of organic nitrogen occurs under field conditions far more slowly than in the laboratory. In spite of the lower yields of mobilizeable nitrogen in the laboratory, the soils K 5 and K 6 have been able to offer markedly higher amounts of nitrogen to the crops than the humus soil. The nitrogen yields are, however, considerably smaller than in $\mathrm{V} 1$ or $\mathrm{V} 2$. In all experiments the application of nitrogen fertilizers tend to enhance the nitrogen in the yield, although, owing to the large variation, this increase is not always statistically significant.

The apparent recovery of the fertilizer nitrogen ranges in these experiments from 24 to 76 per cent of the amount applied. It is distinctly higher in the experiments $\mathrm{K} 5$ and $\mathrm{K} 6$ on soils relatively poor in nitrogen than in the experiments $\mathrm{V} 1$ and $\mathrm{V} 2$ on the soils rich in nitrogen. In the experiment $\mathrm{T} 1$ on the humus soil the recovery of fertilizer nitrogen has been fairly high. 
Table 4. Nitrogen removed by oats in field experiments

\begin{tabular}{|c|c|c|c|c|c|c|c|c|}
\hline & \multicolumn{2}{|c|}{$\mathrm{N}$ applied } & \multicolumn{3}{|c|}{ N kg/ha } & \multicolumn{3}{|c|}{$\begin{array}{l}\text { Apparent recovery as } \\
\% \text { of applied } \mathrm{N}\end{array}$} \\
\hline & & $\mathrm{kg} / \mathrm{ha}$ & Grain & Straw & Total & Grain & Straw & Total \\
\hline \multirow[t]{5}{*}{ V 1} & & 0 & 55 & 12 & 67 & & & \\
\hline & $\mathrm{A}^{*}$ & 25 & 66 & 15 & 81 & 44 & 12 & 56 \\
\hline & & 50 & 67 & 19 & 86 & 24 & 14 & 38 \\
\hline & $\mathrm{B}^{* *}$ & 25 & 59 & 14 & 73 & 16 & 8 & 24 \\
\hline & & 50 & 72 & 17 & 89 & 34 & 10 & 44 \\
\hline \multirow[t]{5}{*}{ V 2} & & 0 & 70 & 18 & 88 & & & \\
\hline & $A^{*}$ & 25 & 81 & 18 & 99 & 44 & 0 & 44 \\
\hline & & 50 & 87 & 22 & 109 & 34 & 8 & 42 \\
\hline & $\mathrm{B} * *$ & 25 & 82 & 18 & 100 & 48 & 0 & 48 \\
\hline & & 50 & 87 & 21 & 108 & 34 & 6 & 40 \\
\hline \multirow[t]{5}{*}{ T 1} & & 0 & 14 & 16 & 30 & & & \\
\hline & $A^{*}$ & 25 & 33 & 15 & 48 & 76 & $(-4)$ & 72 \\
\hline & & 50 & 47 & 20 & 67 & 66 & 8 & 74 \\
\hline & $\mathrm{B}^{* *}$ & 25 & 30 & 15 & 45 & 64 & $(-4)$ & 60 \\
\hline & & 50 & 44 & 19 & 63 & 60 & 6 & 66 \\
\hline \multirow[t]{9}{*}{ K 5} & & 0 & 38 & 12 & 50 & & & \\
\hline & $A^{*}$ & 25 & 47 & 19 & 66 & 36 & 28 & 64 \\
\hline & & 50 & 62 & 26 & 88 & 48 & 28 & 76 \\
\hline & & 75 & 71 & 33 & 104 & 44 & 28 & 72 \\
\hline & & 100 & 72 & 46 & 118 & 34 & 34 & 68 \\
\hline & $\mathrm{B}^{* *}$ & 25 & 47 & 18 & 65 & 36 & 24 & 60 \\
\hline & & 50 & 62 & 22 & 84 & 48 & 20 & 68 \\
\hline & & 75 & 69 & 27 & 96 & 41 & 20 & 61 \\
\hline & & 100 & 66 & 50 & 116 & 28 & 38 & 66 \\
\hline \multirow[t]{3}{*}{ K 6} & & 0 & 34 & 10 & 44 & & & \\
\hline & $\mathrm{A}^{*}$ & 50 & 51 & 23 & 74 & 34 & 26 & 60 \\
\hline & $\mathrm{B}^{* *}$ & 50 & 55 & 20 & 75 & 42 & 20 & 62 \\
\hline
\end{tabular}

*calcium nitrate, ** ammonium nitrate limestone

The proportion of the applied nitrogen recovered appears to vary almost independent on the rate of application. It is also impossible to find any distinct differences in the utilization of nitrogen from the two fertilizers. Some tendency to a slightly better uptake of calcium nitrate nitrogen may be detected in the experiments $\mathrm{T} 1$ and $\mathrm{K} 5$ : in the former one the average apparent recovery of calcium nitrate nitrogen is 73 per cent and of nitrogen in ammonium nitrate limestone 66 per cent; In the latter experiment the corresponding figures are 70 and 64 per cent. Statistically these differences are not, however, quite significant. 
It is of interest to note that the part of nitrogen recovered in the straw yield is negligible or rather low in the experiments $\mathrm{T} 1$ and $\mathrm{V} 2$, while it is quite considerable in the experiments $\mathrm{K} 5$ and $\mathrm{K} 6$, representing in some cases quantities which are equal to or even higher than the corrensponding proportions recovered in grain. This material is far too small to allow any conclusions to be drawn about the connection of this difference with the nitrogen conditions of the soil. It may be also associated with differences in the climatic conditions: the experiments V 1, V 2, and $\mathrm{T} 1$ were carried out in the extremely dry summer 1959, and the experiments $\mathrm{K} 5$ and $\mathrm{K} 6$ in the more favourable season of 1960 .

Table 5. Apparent recovery of nitrogen applied as calcium nitrate and ammonium nitrate limestone by grain yields of oats and barley

\begin{tabular}{|c|c|c|c|c|c|}
\hline & & & $\mathrm{N}$ applied $\mathrm{kg} / \mathrm{ha}$ & Calcium nitrate & $\begin{array}{c}\text { Ammonium nitrate } \\
\text { limestone }\end{array}$ \\
\hline \multirow[t]{2}{*}{ K 1} & Oats & $\ldots \ldots \ldots \ldots \ldots \ldots$ & 25 & $36 \%$ & $28 \%$ \\
\hline & & & 50 & $32 \%$ & $28 \%$ \\
\hline \multirow[t]{2}{*}{ K 2} & Oats & $\ldots \ldots \ldots \ldots \ldots \ldots$ & 25 & $16 \%$ & $24 \%$ \\
\hline & & & 50 & $16 \%$ & $16 \%$ \\
\hline \multirow[t]{2}{*}{ L 1} & Oats & $\ldots \ldots \ldots \ldots \ldots \ldots \ldots$ & 25 & $40 \%$ & $24 \%$ \\
\hline & & & 50 & $32 \%$ & $26 \%$ \\
\hline \multirow[t]{2}{*}{ L 2} & Barley & $\ldots \ldots \ldots \ldots \ldots \ldots$ & 50 & $60 \%$ & $42 \%$ \\
\hline & & & 100 & $48 \%$ & $40 \%$ \\
\hline
\end{tabular}

The apparent recovery of fertilizer nitrogen by the grain yields of oats in the experiments K 1, K 2, and L 1 in 1959, and of barley in 1960 are recorded in Table 5. The recovery appears to be very low in the first two experiments, but the oat grains in L 1 and particularly, the barley grains in L 2 have been able to accumulate a marked part of the fertilizer nitrogen. If the nitrogen content of the straw yield is estimated using probable average values for the percentage of nitrogen in the dry matter, the apparent recovery by the straw will be about 16 per cent in the experiment $\mathrm{K} 1$, from 20 to 28 per cent in $\mathrm{K} 2$, about 12 per cent in $\mathrm{L} 1$, and about 20 per cent in L 2. Thus the total recovery of fertilizer nitrogen would be of the order of 40 to 50 per cent in the experiments $\mathrm{K} 1, \mathrm{~K} 2$, and $\mathrm{L} 1$, and reach the level of 60 to 80 per cent in the experiment $\mathrm{L} 2$. It is, however, better not to consider this kind of calculations valid.

In field studies with wheat at Iowa BLACK et al. (1) found on three soils average recoveries of nitrogen in the grain and straw of 57 per cent, 40 per cent, and 28 per cent from applications of 32,64 , and $128 \mathrm{lb} \mathrm{N} / \mathrm{A}$ respectively. The recovery varied on the different soils from 47 to 66 per cent of the lowest application, and from 9 to 44 per cent from the heaviest dressing. The total nitrogen content of the soil, 0.20 to $0.23 \%$, or the amounts of mineralizable nitrogen, from 2.14 to $2.46 \mathrm{mg}$ $\mathrm{N} / 100 \mathrm{~g}$, do not appear to be correlated with the recovery of the fertilizer nitrogen. 
Attention is paid in the present paper to the conflicting information in the literature about the recovery of fertilizer nitrogen by crops. One reason for this inconsistency is suggested to be the fact that in several cases the difference in the nitrogen content of the crops receiving all the main nutrients and that of the unfertilized crops is supposed to represent the amount of nitrogen taken up from the fertilizer. This has been done even when results of the same experiment distinctly show that an application of potassium or phosphorus fertilizers has markedly increased the amount of nitrogen in the crop as compared with the unfertilized one.

In some Danish and Finnish longterm field experiments the uptake of fertilizer nitrogen by the crops of the whole rotation has been reported to be 60 to 104 per cent. When the apparent recovery of fertilizer nitrogen is computed on the basis of results from treatments which differ only in regard to the nitrogen application, values ranging from 11 to 55 per cent of the amount applied are obtained from these experiments.

In two American longterm rotation experiments with grains the recovery of fertilizer nitrogen varies from 18 to 42 per cent. The present of root crops in the rotation appears to increase the recovery of fertilizer nitrogen. It seems that the residual effect of fertilizer nitrogen is worth some more consideration.

Results of Finnish pasture experiments are in accordance with the statement by Cooke (3) that on the average two thirds to three quarters of the applied fertilizer nitrogen is taken up by grass.

In field experiments carried out with oats by the present institute the apparent recovery of fertilizer nitrogen by grains and straw ranged from 24 to 76 per cent of nitrogen applied as calcium nitrate or ammonium nitrate limestone. In general, the recovery was related to the nitrogen conditions of the soils characterized by the contents of total nitrogen and mobilizeable nitrogen. The relative recovery did not seem to depend on the rate of application. No significant difference could be found between the uptake of nitrogen from the two fertilizers, although some tendency towards a slightly better utilization of calcium nitrate may exist.

The variation in the uptake of fertilizer nitrogen is large, but obviously, the apparent recovery by arable crops, except by root crops, is usually more likely to be less than 50 per cent than to exceed 70 per cent. Therefore, studies on the improvement of the efficiency of nitrogen fertilizers seem to be necessary.

\section{REFERENCES}

(1) Black, C. A. \& Nelson, L. B. \& Pritchett, W. L. 1946 Nitrogen utilization by wheat as affected by rate of fertilization. Soil Sci. Soc. Amer. Proc. 11: 393-396.

(2) Boawn, L. C. \& Nelson, C. E. 1960. Nitrogen carrier and nitrogen rate influence on soil properties and nutrient uptake by crops. Wash. Agr. Expt. Sta. Bull. 614.

(3) Сооке, G. W. 1964. Nitrogen fertilisers: Their place in food production, the forms which are made and their efficiencies. Proc. Fertiliser Soc. No 80.

(4) Hänninen, P. \& KAILA, A. 1961. Calcium nitrate and ammonium nitrate limestone as sources of nitrogen for oats and barley. J. Sci. Agr. Soc. Finland 33: 159-169. 
(5) Iversen, K. 1943. Staldgødningens og Kunstgødningens Kvaelstof-, Fosforsyre- og Kalivirkning. Tidskr. f. Planteavl 47:1-93.

(6) - - \& Dorph-Petersen, K. 1949. Forsøg med staldgødning og kunstgødning på sandjord ved Lundgaard og Tylstrup, 1927-46. Ibid. 53: $33-84$.

(7) - - \& - 1951.Forsøg med staldgødning og kunstgødning ved Askov $1894-1948$. Ibid. 54: $369-538$.

(8) JÄNTTI, A. \& KöYLIJÄRVI, J. 1964. Laidunnurmien typpiväkilannoituskokeiden tuloksia. (Results of nitrogen fertilization on pasture). Ann. Agr. Fenn. 3: 165-214.

(9) Kofoed, A. D. \& Søndergand, Klausen, P. 1964. Forsøg med stigende maengder kvaelstof till staldgødet og icke staldgødet jord. Tidskr. f. Planteavl. 68: 23-28.

(10) Lipman, J. G. \& Blair, A. W. \& Prince, A. L. 1928. Field experiments on the availability of nitrogeneous fertilizers, 1923-1927. Soil Sci. 26: 1-25.

(11) Nieschlag, F. 1963. Die Düngung in der Praxis. Hamburg, 136 p.

(12) Russell, E. W. 1961. Soil conditions and plant growth. London, 688 p.

(13) SAlonen, M. \& TAINIO, A. 1956. Savimaan lannoitusta koskevia tutkimuksia. Summary: Investigations concerning the manuring and fertilizing of clay soil. Publ. Finnish State Agr. Res. Board No 146. Helsinki, 86 p.

(14) Schmalfuss, K. 1952. Pflanzenernährung und Bodenkunde. 5 Aufl. Stuttgart, 274 p.

(15) Selke, W. 1955. Die Düngung. Berlin, 347 p.

(16) Wagner, P. 1915. Die Wirkung von Stallmist und Handelsdüngern. A. D. L. G. Heft 279.

(17) Waring, S. A. \& Bremner, J. M. 1964. Ammonium production in soil under waterlogged conditions as an index of nitrogen availability. Nature (London) 201: 951-952.

(18) White, J. W. \& Holben, F. J. 1931. Nitrogen balance in a four-year grain rotation. J. Amer. Soc. Agron. 23: 723-740.

SELOST US:

\title{
VÄKILANNOITTEIDEN TYPEN HYVÄKSIKÄYTÖSTÅ
}

\author{
Armi KaIla
}

Yliopiston maanviljelyskemian laitos, Pihlajamäki

Todettiin, että kirjallisuudessa esiintyvăt ristiriitaiset tiedot lannoitetypen hyväksikäytöstä johtunevat osittain siitä, että lannoitetypen otto on usein laskettu täyslannoituksen saaneen ja lannoittamattoman koejäsenen typpisatojen erotuksena. Koska kuitenkin kali- ja fosforilannoitus voi huomattavasti parantaa kasvien typen ottoa, saadaan täten usein virheellisen suuria arvoja.

Eräissä tanskalaisissa ja suomalaisissa kiertokokeissa on lannoitetypen hyväksikäytön ilmoitettu olevan $60-104 \%$. Hyväksikäyttöprosentit osoittautuvat kuitenkin olevan vain $11-55 \%$, jos lannoitetypen otto lasketaan sellaisten koejäsenten typpisatojen erotuksena, jotka eroavat toisistaan vain typpilannoituksen suhteen.

Pitkäaikaisissa amerikkalaisissa viljakasvikierroissa on eri lannoitteiden typenkäyttö ollut 18$42 \%$. Jos kierrossa on mukana juurikasveja, saadaan yleensä korkeampia arvoja.

Suomalaiset laidunkokeet vahvistavat käsitystä, että tavallisesti nurmikasvit ottavat $2 / 3-3 / 4$ lannoitetypestä.

Laitoksen kenttäkokeissa todettiin kauran käyttäneen $24-76 \%$ annetun kalkkisalpietarin tai oulunsalpietarin typestä. Kivennäismaissa lannoitetypen hyväksikäytön taso oli selvästi matalampi silloin, kun maassa oli runsaasti mobilisoituvaa typpeä. Käyttöprosentti ei näyttänyt riippuvan lannoitteen määrästä, eikä eri lannoitteiden hyväksikäytössä ollut selvää eroa, joskin kalkkisalpietari năytti eräissä kokeissa olevan hiukan parempi tässä suhteessa.

Ilmeisesti lannoitetypen hyväksikäyttö vaihtelee hyvin paljon, mutta lienee muilla paitsi nurmikasveilla ja juurikasveilla yleensä alle $50 \%$. Lannoitetypen hyväksikäytön tehostamismahdollisuuksia on siis syytä tutkia. Toisaalta näyttää olevan syytä kiinnittää huomiota myös typpilannoitteiden jãlkivaikutuksen selvittämiseen. 